
AND INSTRUMENTAL METHODS OF ECONOMICS

\author{
УДК 624.012.4: 699.812
}

УКРАЇНСЬКА Л.О. ${ }^{*}$, МАЩЕНКО М.А. ${ }^{2}$

1* д.е.н., професор, професор кафедри економічної теорії та економічної політики, Харківський Національний економічний університет імені Семена Кузнеця, e-mail: ukrainskalarisa@ gmail.com

$2^{*}$ д.е.н., доцент, завідувач кафедри економічної теорії та економічної політики, Харківський Національний економічний університет імені Семена Кузнеця, e-mail: mmashchenko@ukr.net

\title{
ЦИФРОВІЗАЦІ ГРОШОВИХ ІНСТРУМЕНТІВ: ПРОБЛЕМИ ДЕРЖАВНОГО КОНТРОЛЮ І РЕГУЛЮВАННЯ
}

Мета. Дослідження і порівняльна характеристика цифрових грошових інструментів в ході їх еволюції. Методика. В процесі дослідження використані загальнонаукові методи дослідження, абстрагування і конкретизація; системний аналіз. Результати. Досліджено еволюцію грошових інструментів в умовах переходу до цифрової економіки, узагальнено суть та особливості різних видів електронних грошей, виявлено переваги і недоліки технології блокчейн і криптовалюти, розкрито перспективи введення цифрових валют і криптовалюти СBDC центробанків. Наукова новизна. Узагальнено суб'єктивні підходи до визначення цінності криптовалюти; переваги стимулювання спільного управління базою даних щодо розрахунків і реалізації інвестиційних проектів за допомогою технології блокчейн. Практична значущість. Рекомендації щодо активізації державного регулювання обігу криптовалют.

Ключові слова: цифрова економіка, грошові інструменти, електронні гроші, цифрові гроші, криптовалюта, блокчейн, СBDC.

\section{Постановка проблеми}

Одним 3 центральних напрямів розвитку світової економіки, є прискорення зміни технологічних укладів, що, супроводжуються зростанням ролі інформаційнокомунікаційних технологій в усіх економічних i соціальних процесах в суспільстві, що, в свою чергу істотно розширює можливості використання нових форм грошей на електронних носіях. Проте еволюція грошей не повинна порушувати загальні закономірності функціонування грошового механізму. У числі найважливіших з них - гнучкість грошової пропозиції, тобто іiі здатність змінюватися при зміні фаз економічного циклу.

\section{Аналіз останніх досліджень та публікацій}

Стрімкий розвиток $\mathrm{i}$ поширення сфер застосування цифрових форм грошових інструментів випереджає наукове дослідження питань їх змісту, суті і їх ролі в опосередкуванні товарно-грошового обігу. Незважаючи на широке застосування, наукове розуміння суті i особливостей функціонування нових фінансових інструментів $\epsilon$ певною мірою поверхневим i потребує подальших поглиблених досліджень. Слід також зауважити, що наявні підходи до визначення відповідних категорії мають певні розбіжності внаслідок структурних особливостей, рівней розвитку тощо між різними країнами $[5,3,7,11]$. Тому i стратегічні пріоритети різних держав в галузі визначення сфер застосування, розвитку i регулювання обігу цифрових грошей не однакові. В першу чергу це стосується дослідження впливу криптовалют і технології блокчейн на ринкову рівновагу, відповідності обігу криптовалют вимогам законів грошового обігу, можливостей i механізмів державного регулювання цього обігу $[1,4]$. Цим і визначаються подальші напрями наукових досліджень. 


\section{Формулювання мети статті}

Метою цієї роботи $є$ дослідження i порівняльна характеристика цифрових форм грошових інструментів, перспектив і проблем ix застосування бізнесом i фізичними особами, обгрунтування необхідності державного контролю і регулювання, з метою запобігання кризових явищ у товарногрошовому обігу і фінансовій сфері.

\section{Виклад основного матеріалу}

Розвиток інформаційно-комунікаційних технологій $\epsilon$ тим підгрунтям, на якому сформувалися основи цифрової економіки. Цифрова економіка в науковому сенсі $\epsilon$ економічною категорією, що, з одного боку, відображає певні виробничі відносини, що мають місце між учасниками в процесі інформатизації суспільного виробництва, i, 3 іншого, - $є$ надсучасним методом господарювання. Відповідно, як відображення реальних процесів, що відбуваються i прискорюються в суспільному виробництві, в науковий і політичний обіг увійшов термін «цифрова економіка» [9 ].

В результаті з'явилися i стрімко розвиваються нові ринки, нові форми комунікацій, нові підходи до організації та управління виробництвом товарів і надання послуг. Цифровізація сприяла певним і досить істотним змінам у світогляді - поряд 3 матеріальними або «відчутними» цінностями, з'явилися цифрові: починаючи від прав на об'єкти інтелектуальної власності і закінчуючи персонажами в комп'ютерних онлайн-іграх.

Ці товари і послуги стали обертатися на глобальному цифровому ринку, який 3 моменту своєї появи не мав географічних кордонів. Особливістю цього ринку є те, що переважна більшість товарів і послуг споживаються i використовуються в цифровому просторі, наслідком чого $\epsilon$ прискорення комунікації між продавцями i покупцями і постачання цифрових продуктів. $\mathrm{У}$ той же час обслуговування угод купівліпродажу здійснювалося/здійснюється 3 використанням фіатних грошей і банківської інфраструктури.

Зіткнення цифрового середовища $\mathrm{i}$ аналогових каналів передачі цінностей призводило до невідповідності швидкості і вартості транзакцій можливостям цифрового середовища і потребам учасників угод, до того ж мав місце ризик втрати цифрової власності і грошей в результаті шахрайських дій третіх осіб $[9,11]$.

Потреба в вирішенні цих проблем посилилась внаслідок світової фінансовоекономічної кризи 2007-2009 років, а також таких чинників, як дестабілізація міжнародних економічних відносин через ускладнення умов торгівлі 3 країнами, що розвиваються 3 боку провідних держав, введення економічних санкцій $\mathrm{i}$ широке застосування інструментів протекціонізму. Такі умови стали підставою запиту зацікавлених сторін на формування альтернативних інструментів супроводження i опосередкування торгівельних угод, заощадження накопичень, які не корелюють 3 динамікою традиційних фінансових ринків, нових еквівалентів грошей, що $є$ іманентними сучасним вимогам цифрової економіки i певною мірою незалежні від дій країнемітентів.

Активізація обороту продуктів супроводжується появою i розвитком інноваційних фінансових інструментів. Фінансові інновації різними авторами визначаються як дії зі створення i популяризації нових фінансових інструментів, а також нових фінансових технологій, ринків та інститутів, або, ширше, - як акт створення, a потім популяризації нових фінансових інструментів, технологій, установ, ринків, процесів і бізнес-моделей, в тому числі нового застосування, існуючих ідей в іншому контексті ринку $[8,10]$. Однак, і автори це визнають, визначення не охоплюють всю складність інновацій в сфері фінансових послуг, де один новий продукт може об'єднувати різноманітні інноваційні функції: обіг, організаційну форму, маркетинг та інший клієнтський сегмент, а також розвиток допоміжної інфраструктури.

Фінансові інновації з'являються i розвиваються як інструменти прискорення обороту товарів і послуг як споживчого так i виробничого призначення, розвитку самих фінансових технологій, а також як результат пошуку конкурентних переваг для їх ініціаторів. Поряд зі створенням конкурентних переваг фінансові інновації дозволяють вигідніше використовувати накопичення для інвестиційних цілей. У свою 
чергу, нові фінансові інструменти, будучи одним із засобів конкурентної боротьби, в певному сенсі сприяють економічному прогресу, насичуючи попит на грошовому ринку, прискорюючи інвестиційний процес.

Слід зауважити, що однією 3 ключових характеристик товару, що розглядається як еквівалент грошей, $\epsilon$ його цінність. Так, цінність фіатних грошей формувалася історично: 3 моменту їх появи, подальшої прив'язки до золотого стандарту і закінчуючи гарантіями країн-емітентів. На сучасному етапі роль і статус держави багато в чому визначають довіру і цінність фіатних грошей. В цілому ж платіжні і транзакційні системи оцінюються за такими критеріями, як безпека, ефективність, надійність і швидкість. Щоб мати конкурентні переваги, нова система повинна запропонувати поліпшення принаймні в одному 3 цих вимірів: готівкові гроші були краще, ніж бартер, тому що торговельні партнери більше не повинні були покладатися на те, що обидві сторони мають в точності те, що хоче інша сторона. Кредитні або дебетові картки часто більш ефективні, ніж готівка, оскільки платежі обробляються електронним способом i, отже, не вимагають локальної передачі. Крім того, втрата вашої кредитної/дебетової картки автоматично не призводить до втрати кредиту, що є значною перевагою перед готівкою. Те ж саме відноситься до банківських переказів, які переважно застосовувались для великих сум.

Поява криптовалют стала спробою технологічної відповіді на виниклі проблеми і виклики трансформації світової економіки і діючої системи державного регулювання. Криптовалюта $\epsilon$ продуктом цифрової економіки; інтернаціональним продуктом, створеним в інтересах і для обслуговування всіх учасників розрахунків, при створенні якого застосовуються алгоритми, засновані на об'єктивних математичних законах; контроль обігу криптовалют здійснюється самою системою, що робить цю систему більш стійкою по відношенню до дій третіх осіб; до того ж криптовалюта дозволяє знижувати трансакційні витрати, полегшує зберігання та трансфер цінностей. Таким чином за окремими критеріями криптовалюта навіть більш приваблива у використанні, ніж функціонуючі в обігу види грошей[10].

Проте, якщо обсяги цифрових грошей як i інших форм грошового матеріалу, що емітуються державою, контролюються у відповідності до потреб обслуговування руху товарів, то криптовалюта в переважній більшості випадків не забезпечена будь яким товаром і не гарантована державою. Таким чином, іiі цінність визначається одночасно виходячи 3 індивідуального сприйняття і від того, як вона оцінюється іншими членами суспільства, тобто рівнем довіри до неї. Існуючи тільки у вигляді програмного коду i маючи ризик стабільності, обмежені можливості прямого обміну на товари (функція платіжного засобу), технічні обмеження і складнощі, пов'язані з майнінгом та обігом, криптовалюта проте використовується в ролі грошей. Її унікальність по відношенню до фіатним грошей полягає також в тому, що іiі обмеженість в обороті i можливість регулювання фактично забезпечуються без участі держави. Випуск криптовалюти розглядається також як зручний спосіб залучення приватних інвестицій для фінансування запуску i/aбо фінансового забезпечення поточних бізнес-проектів.

Слід зауважити, що значення перспектив використання криптовалюти для громадян, держави і бізнесу різниться. 3 точки зору бізнесу це, перш за все, інший формат взаємодії економічних агентів із скороченням числа посередників в особі банків, державних і квазідержавних інститутів. На практиці це означає мінімізацію бюрократичних формальностей для здійснення розрахунків, збільшення швидкості надання послуг, зниження вартості проведення транзакцій. Згода сторін-учасників визнавати криптовалюту в якості засобу платежу/обігу передбачається.

Окрему цінність може представляти незворотність транзакцій в порівнянні 3 можливістю скасування будь-якої банківської транзакції або оспорювання і розірвання угод в судових інстанціях. Проте, щодо цього аспекту є питання, оскільки учасники угоди, що забезпечується криптовалютой, мають бути впевненими у якості і кількості товару, рух якого опосередкується крипто-грошима.

Тут доцільно зауважити, що, не зважаючи на ефективність електронних платіжних систем, у них $\epsilon$ один істотний недолік. Усі транзакції повинні бути оброблені в центральній точці з метою запобігання так званих «подвійних витрат» тобто випадків, 
коли людина намагається витратити електронні гроші декілька разів. Ця проблема не існує 3 фізичними засобами платежу, такими як готівка, оскільки кожна монета i банкнота існує тільки один раз, і одиниця виміру вартості об'єкта передається новому власнику на відміну від електронних даних які можна копіювати так часто, як буде завгодно. В цьому зв'язку слід акцентувати увагу на тому, що емітенти електронних грошей не повинні мати можливість їх копіювання/відтворення, для збереження властивості умовного еквівалента вартості об'єктів угод.

Для запобігання можливості відтворення електронних грошей центральною базою даних підтримується баланс електронних рахунків учасників, що позбавляє будь-кого можливості витрачати більше, ніж він фактично володіє, або перевищувати свої ліміти. Завдяки цьому централізовані бази даних мають високий ступінь ефективності. Одночасно є певні загрози їх ефективному функціонуванню, яким існують географічні та історичні приклади. Так володіння винятковою можливістю ведення i контролювання бази даних, визначення поточного статусу несе загрози конфіскації грошей, обмеження транзакції або виключення певних осіб тощо [10].

Певні переваги в цьому сенсі $\epsilon$ у технології блокчейн яка забезпечує можливість спільного управління базою даних. У загальнодоступних мережах кожен учасник може зберігати копію цієї бази даних i незалежно перевіряти достовірність усіх записів. Складна система стимулювання означає, що в інтересах кожного учасника продовжувати керувати своєю власною базою даних відповідно до загальних правил. Це дозволяє різним базам даних працювати узгоджено, і завжди існує консенсус щодо того, які транзакції дійсні. Якщо людина вносить зміни в свою власну копію бази даних, які не відповідають правилам, ця версія може бути негайно визначена як недійсна іншими учасниками мережі і може бути відповідним чином проігнорована. Оскільки жоден 3 учасників мережі не грає привілейованої ролі і дані зберігаються всюди, кластерний ризик відсутній, як в централізованих системах. Кожен учасник може бути замінений, і мережеві підключення можуть адаптуватися динамічно, якщо окремі учасники повинні бути виключеними [12].

Цікаво, що компоненти технології блокчейн існують вже багато років, наприклад, у вигляді децентралізованих однорангових мереж. Те ж саме відноситься до криптографії 3 відкритим ключем i хешфункціями, які використовуються для перевірки транзакцій i досягнення консенсусу, але нововведенням $\epsilon$ те, яким чином ці технологічні компоненти пов'язані і об'єднуються в загальну систему. Тільки завдяки цим посиланням стало можливим зберегти віртуальні одиниці вартості повністю незалежними 3 усіма перевагами і недоліками.

Проте така автономія означає велику відповідальність. Якщо ваш власний ключ доступу, так званий «закритий ключ», загублений або потрапив в руки третьої сторони, одиниці крипто-значення безповоротно зникнуть. В результаті багато людей зберігають свої крипто-активи у кастодіальних провайдерів, що суперечить загальному духу публічної блокчейн.

3 точки зору інвестора блокчейн може також використовуватися для інших цілей, наприклад, компанії можуть випускати одиниці крипто-вартості, так звані маркери, які представляють цінні папери. Дивіденди і відсотки виплачуються автоматично. Реалізація торгівельних угод здійснюється інвестором на будь-якому 3 децентралізованих біржових майданчиків на основі автономних контрактів, а будь-яке право голосу може бути реалізованим шляхом використання електронного підпису - швидко i безпечно. На відміну від криптовалюти, такі маркери схильні до ризику емітента. Проте, ці криптовалютні одиниці також можуть значно виграти від децентралізації під час передачі і зберігання оскільки і тут варіант незалежності з економічної точки зору абсолютно вітається, а децентралізація веде до створення більш надійних систем.

Слід зауважити, що технологія блокчейн не позбавлена недоліків, які перешкоджають iï масовії адаптації, зокрема розмір блокчейна, відсутність конфіденційності, енерговитратність тощо. До того ж ця технологія не завжди застосовується за призначенням, що призводить до певного розчарування. 
Проте технологія блокчейн має дуже високий потенціал, за умови, що вона використовується правильно. Таким чином, можна сказати, що широта застосування блокчейна сьогодні явно завищена, в той час як вплив, який блокчейн надає на ті області, в яких він може успішно використовуватися, явно недооцінюється.

Що стосується фізичних осіб, до розгляду феномена криптовалюти i технології блокчейн можна підходити з різних аспектів, зокрема як до дешевого інструменту для великих розрахунків, також як до засобу отримання доходу за рахунок інвестицій в покупку криптовалюти і Майнінг.

На сьогоднішній день масштаб використання криптовалюти не дає підстав вважати, що більшість суб'єктів світової економіки відходять від використання фіатних грошей на користь криптовалюти. Зростаючий інтерес населення до криптовалюти був більшою мірою обумовлений можливістю вкладення грошових коштів і одержання надприбутку за рахунок зростання котирувань криптовалюти. При цьому багато експертів вважають, що вкладення в цифрові гроші це «фінансова піраміда», i незабаром фінансовий міхур повинен лопнути або вже лопнув [13].

Фактори динаміки вартості криптовалюти слабо прогнозовані, що відбивається на істотних скачках курсу криптовалюта по відношенню до фіатним грошей. При тому, що актив не забезпечений реальною цінністю, потенційна прибутковість за рахунок операцій купівлі-продажу дуже висока, що робить вкладення в криптовалюта дуже ризикованими і одночасно привабливими для спекулятивного капіталу. Можна міркувати про «переоціненість» або «недооціненість» криптовалюти, але при цьому необхідно розуміти, що ці терміни застосовні в більшій мірі до фіатним грошей. У діяльності, пов'язаної $з$ криптовалютою, простежуються певні тенденції розвитку. Деякі компанії починають експериментально допускати оплату своїх товарів і послугу криптовалюті, окремі країни створюють правові рамки обігу криптовалюти на своїй території (юрисдикції). Говорячи про тренд в цілому, можна констатувати, що країни все ще «придивляються» до даного феномену, визначаючи баланс між потенціалом розвитку цифрових технологій і ризиками ослаблення державного контролю.

Дійсно, комп'ютерна програма 3 математичним алгоритмом в своїй основі дозволяє організувати саморегульовану грошову систему, разом 3 тим досі не зрозумілий механізм взаємодії цієї системи 3 функціонуванням державної фінансової системи. Окрім того тут криються загрози втрати контролю 3 боку держави за рівновагою товарної і грошової маси в обігу, порушення стійкості товарно-грошового обігу, можливості негативного впливу застосування криптовалют на стабільність національної валюти тощо.

Центробанки багатьох країн активно обговорюють введення цифрових валют центральних банків (central bank digital currencies, CBDC). А окремі держави вже експериментують 3 цифровими грошима, а також технологією блокчейн. Першим великим Центробанком, що розпочав в умовах секретності практичну підготовку до введення цифрової валюти, був Народний банк Китаю (НБК). Серед «першопрохідців» можна назвати також центробанки Швеції, Південної Кореї. На середину 2020 року, за даними Банку міжнародних розрахунків (БМР), принаймні шість центробанків здійснювали практичні роботи по створенню цифрових валют. А заяви про інтерес до цифрових валют зробили вже десятки центробанків. 32018 року БМР почав вести моніторинг діяльності центробанків у сфері національних цифрових валют. У серпні 2020 року було оприлюднено дані опитування БМР, що охоплює центробанки країн, на які припадає 90\% світового ВВП [4].

Китай позитивно сприймає нові фінансові технології, цифрові платежі тут набули надзвичайно широкого застосування. Саме тому китайський уряд запустив програму офіційної цифрової версії своєї валюти, плануючи протестувати ii під час Олімпійських ігор в Пекіні в 2022 році. За прогнозами економістів, оновлена фінансова система не лише може зміцнити владу уряду, але і скоригувати баланс економічного впливу в світі. До речі, особливу стурбованість 3 цього приводу відчувають Сполучені Штати, так як цифровий юань може стати новою загрозою фінансового домінування США. В цілому думка американських аналітиків зводиться до того, що КНР готує технологію, 
яка може стати вбивцею не тільки для біткоіна, але i принести великі проблеми американському долару [3].

Нові цифрові фінансові інститути та провайдери банківських послуг, так звані необанкі, все активніше завойовують Швейцарію. Їх послуги і пропозиції, як видно, відповідають сучасним тенденціям розвитку банкінгу, що підтверджує той факт, що цюрихский банк Neon зміг тільки за останній рік залучити 30000 нових клієнтів. Кредитні карти i послуги цифрового банкінгу пропонуються такими структурами в інноваційній та прозорій формі, та ще й на надзвичайно вигідних умовах. Зі своїми клієнтами банк спілкується виключно по цифрових каналах. Перевагами є швидкість і простота здійснення банківськіх операцій, економія на операційних комісіях і зборах за ведення розрахункового рахунку [8].

Національний банк України вже не перший рік вивчає ймовірність введення в ужиток так званих е-гривень, при цьому перші законопроекти в парламент 3 цього приводу були внесені ще в 2016 році. В НБУ чітко уявляють, що перехід до цифрових грошей буде поступовим. Регулятор бере до уваги не тільки фінансовий ринок України, а й досвід світових держав, які вже втілили подібні проекти в життя. Слід зауважити, що ринок віртуальних активів в Україні досить розвинений i має значні обороти навіть у світовому масштабі, але його велика частина зосереджена в сірій зоні, що створює потенційні ризики як для держави, так і для бізнесу i користувачів. Тому Мінціфри продовжує створювати правове поле для регулювання ринку віртуальних активів в Україні, зокрема готується законопроект про внесення змін до Податкового кодексу стосовно легалізації в Україні ринку віртуальних активів [5,6].

Цифрові гроші відповідають вимогам, що пред'являються до грошового товару, а також можуть здійснювати деякі функції фіатних грошей і золота. Цінність цифрових грошей не може бути виміряна стандартними підходами, які застосовуються до аналізу фіатних грошей. У порівнянні $з$ традиційною грошовою системою цифрові гроші складно надрукувати у надмірній кількості i, тим самим, викликати інфляцію, адміністративно обмежити/заборонити використання i проведення операцій $з$ криптовалютою. Таким чином, зовнішній вплив сильних гравців (держав) i ïx валют на криптовалюту $\epsilon$ обмеженим. У перспективі це може забезпечити стабільну вартість цифрових грошей у часі (вартість фіатних грошей 3 плином тривалого проміжку часу, як правило, знижується).

Що стосується забезпечення стійкости товарно-грошовоих відносин невирішеними $є$ низка питань, а саме: чи зможе криптовалюта довести практичну ефективність по відношенню до фіатних, цифрових грошей, а також до золота; який саме вплив спричинить поширення використання криптовалют в якості засобів платежу і обігу на інфляційні процеси. I важливішим $є$ питання, як саме держава буде взмозі контролювати обіг криптовалют. Поки що має місце паралельний обіг криптовалют фактично поза державним контролем і поза законодавчим простором.

Одим 3 прикладів реагування на протизаконне обслуговування кримінального обігу $є$ факт конфіскації Міністерством юстиції США десятків тисяч біткоінів, які були переведені 3 гаманця, пов'язаного роботою онлайн-наркоринку Silk Road [1]. Тобто поки що мають місце поодинокі спроби втручання держави в обіг криптовалюти, проте $\epsilon$ очевидною необхідність створення правового простору обігу криптовалют насамперед 3 метою виявлення фактів обслуговування криптовалютою обігу тіньового сектору, немаловажною $є$ i можливість додаткових надходжень за рахунок оподаткування операцій 3 криптовалютой.

3 метою розробки міжнародних правил щодо регулювання емісії та обігу криптовалют Центробанки СС, Англії, Швеції, Швейцарії, Японії та Канади створили робочу групу з Банком міжнародних розрахунків для проведення оцінки потенційних випадків використання цифрових валют центральних банків, економічні, функціональні і технічні варіанти такого використання. Робота цієї робочої групи передбачає обмін відповідними знаннями в галузі технологій, що розвиваються, транскордонну взаємодію, сприяння міжнародному співробітництву між центральними банками i полегшення міжнародних розрахунків. До того ж планується прискорення розробки правил для введення криптовалюти CBDC (Central Bank 
Digital Currency), яка буде випускатися самими центробанками. Діючи в цьому напрямі, ЄЦБ і Банк Японії вже об'єднали зусилля для вивчення можливого використання технології розподіленого реєстру (блокчейн) в інфраструктурі фінансових ринків [4,7].

Слід зауважити, що СBDC по відношенню до фіатних грошей має певні особливості. Емітентом CBDC, як і в випадку з Фіатом, виступає Центробанк країни, що робить національну криптовалюту централізованим фінансовим інструментом, рух якого контролюється єдиним органом. Однак на відміну від фіатних грошей, всі операції 3

\section{Висновки}

Цифровізація грошових інструментів - це наступний крок в еволюції платіжних систем в цифрову економіку. Ймовірні ризики ослаблення регулятивних можливостей держави вимагають більш ретельної оцінки ефектів від використання криптовалюти i зіставлення іï результатів 3 потенційними масштабами реформування державної системи регулювання економіки. Очевидно, що необхідним $\epsilon$ вивчення особливостей, розробка механізму i практичне втілення оподаткування майнінгу і обігу криптовалют. криптоактівом можна перевести в цифровий формат, що надає йому в перспективі додаткові переваги у вигляді зниження операційних витрат; прискорення проведення операцій; поліпшення якості роботи платіжних систем за рахунок автоматизації процесу.

Наступним логічним кроком має стати об'єднання зусиль центральних банків i спільне вивчення практичної здійсненності цифрових валют центробанків, заснованої на загальних технічних стандартах. Розпочинається легалізація ринку кріптоактівов.

В свою чергу введення центральними банками в обіг криптовалюти CBDC гарануватиме ऑiі стійкість, забезпеченість певними резервами, контрольований обіг коштів, відстеження руху грошових потоків. Ймовірним $\epsilon$ також перехід певної частки обігу криптовалют у простір регульований державою. Таким чином влада отримає необхідні інструменти для боротьби 3 тіньовими і протизаконними діями.

\section{UKRAINSKA L.O. ${ }^{1^{*}}$, MASCHENKO M.A. ${ }^{2 *}$}

1* doctor of Economics, Professor, Professor of the Department of Economic Theory and Economic Policy, Kharkiv National Economic University named after Semyon Kuznets, e-mail: ukrainskalarisa@ gmail.com

2* Doctor of Economics, Associate Professor, Head of the Department of Economic Theory and Economic Policy, Simon Kuznets Kharkiv National University of Economic, e-mail: mmashchenko@ukr.net

\section{DIGITALIZATION OF MONEY INSTRUMENTS: PROBLEMS OF STATE CONTROL AND REGULATION}

Goal. Research and comparative characteristics of digital monetary instruments in the course of their evolution. Methodology. During the research, general scientific research methods, abstraction and concretization were used; system analysis. Results. The evolution of monetary instruments in the context of the transition to a digital economy is investigated, the essence and features of various types of electronic money are generalized, the advantages and disadvantages of blockchain technology and cryptocurrency are revealed, the prospects for the introduction of digital currencies and CBDC cryptocurrencies of central banks are revealed. Scientific novelty. Subjective approaches to determining the value of a cryptocurrency are generalized; advantages of stimulating joint management of the database on calculations and implementation of investment projects using blockchain technology. Practical significance. Recommendations for activating state regulation of cryptocurrency circulation.

Keywords: digital economy, monetary instruments, electronic money, digital money, cryptocurrency, blockchain, CBDC 


\section{REFERENCES}

1. Vlasti SShA iz'yali bitkoinyi na \$1 milliard. URL: https://www.vesti.ru/hitech/article/2482019

2. Est li zhizn posle halvinga: chto zhdet pervuyu kriptovalyutu? 06 maya 13:40. 2020. URL: https://www.vesti.ru/finance/article/2406951

3. Kitay gotovit «ubiytsu» bitkoina i novyie problemyi dlya dollara. URL: https://finobzor.ru/98967-kitay-gotovitubiycu-bitkoina-i-novye-problemy-dlya-dollara.html

4. Kriptovalyute propishut mezhdunarodnyie pravila. // "Коммерсант" від 21.01.2020, 20:27 https://www.kommersant.ru/doc/4226541

5. Mayning po-ukrainski. 03:27 / 13.05.2020. URL: https://e-news.su/mnenie-i-analitika/331701-mayning-poukrainski.html

6. Mintsifryi: Ukraina - mirovoy lider po ispolzovaniyu kriptovalyut. 1 sentyabrya, 17:30. Finance.bigmir.net. 2020. URL: http://finance.bigmir.net/news/108809-Mincifry--Ukraina---mirovoj-lider-po-ispol-zovaniju-kriptovaljut

7. Minfin predlozhil lishat svobodyi za nedeklarirovanie kriptovalyut. 12 ноября 2020. URL: https://www.vesti.ru/finance/article/2484274

8.Tsifrovyie banki brosili vyizov shveytsarskoy finansovoy industrii. URL: https://www.swissinfo.ch/rus/neon_campaign=top\&utm_medium=email\&utm_source=newsletter\&utm_content=o 9. Ali R., Barrdear J., Clews R., Southgate J. The economics of digital currencies. Bank of England Quarterly Bulletin, 2014, vol. 54, no. 3, pp. 276-286.

10. Athanassiou Ph., Mas-Guix N. Electronic money institutions. Current trends, regulatory issues and future prospects. ECB Legal Working Paper Series, 2008, no. 7, 50 p. URL: https://www.ecb.europa.eu/pub/pdf/scplps/ecblwp7.pdf?21a28d70b208180883a898dad73451c4

11.Badev A., Chen M. Bitcoin: Technical Background and Data Analysis. Federal ReserveBoard. Finance and Economics Discussion Series, 2014. URL: www.federalreserve.gov/econresdata/feds/2014/files/2014104pap.pdf

12. Fung B., Halaburda H. Understanding platform-based digital currencies. Bank of Canada Review, 2014, pp. 1220. URL: http://www.bankofcanada.ca/wp-content/uploads/2014/05/boc-review-spring4-fung.pdf

13. McLeay M., Radia A., Thomas R. Money creation in the modern economy. Bank of England Quarterly Bulletin 2014. URL:

http://www.bankofengland.co.uk/publications/Documents/quarterlybulletin/2014/qb14q1prereleasemoneycreation.pdf

Стаття надійшла до редакції: 27.05.2021

Received: 2021.05.27 